\title{
Challenges And Key Success Factors Of African Descent Foreign-Owned SMES In The Eastern Cape Province Of South Africa: A Case Of Selected Towns
}

\author{
Masocha Reginald \\ University of Limpopo, Turfloop, South Africa \\ Email: reemasocha@gmail.com \\ Charamba Millicent \\ University of Fort Hare, Alice, South Africa
}

\section{Doi:10.5901/mjss.2014.v5n4p59}

\begin{abstract}
On the backdrop of contemporary environmental transformations where competition has been unwarrantedly sprouting in the business world, SMEs especially, coping with higher demands in maximising their efficiency and competitiveness is inexcusable. The performance of the South African currency, availability of resources and improved infrastructure continue to attract citizens of other African countries e.g. Somalia, Nigeria and Zimbabwe, to start businesses in South Africa. Besides the already acknowledged numerous challenges faced by SMEs, these typology of small enterprises, herein termed AFRICAN DESCENT FOREIGN-OWNED SMES seem to have additional challenges embedded in internalisation of business, as well as, troubled countries of origin. Despite these challenges, foreign SMEs continue to increase and spread in South Africa. A quantitative research was conducted on foreign-owned small businesses in the targeted area using questionnaires. The research focused on identifying challenges of this typology of SMEs and their key success factors. Herein, these factors are classified as entrepreneurial, managerial and marketing success factors.
\end{abstract}

Keywords: Foreign-Owned African SMEs, Key Success Factors, Challenges

\section{Introduction}

SMEs in Emerging Economies (EE) have since been more competitive and crucial for economic growth (Newberry, 2006), prompting for increased government interest and other stakeholders with the aim to contribute toward their potential success in South Africa. Likewise, African countries are increasingly strategically structuring their economic policies regarding SMEs. In South Africa, the White Paper on National Strategy for the Development and Promotion of Small Business (1995) reinvented the wheel of small business development (van Vuuren, 2002). A major concern is still the unsuccessful rate and closure of small businesses at large (Botha \& Esterhuyzen, 2013:332; van Vuuren, 2002). The majority of failure is attributed at the infancy stage and relatively a larger proportion fails within a few years after start-up. Hellriegel, Slocum, Jackson, Staude, Amos, Klopper, Louw \& Oosthuizen, (2004) opine that substantially many of those who fail do not have the tolerance for hard work. An increasingly observed business phenomenon, regardless of these cacophonic and challenging business circumstances for SMEs, is the escalating number of foreign nationals operating small businesses in South Africa.

Noticeably, despite of rapidly changing environment factors and numerous issues impacting on their future viability, foreign-owned small businesses in South Africa are increasing. In addition to these rapid changes, it is expected that foreign SMEs face unique challenges from setting up businesses to operational challenges. Kotler \& Keller, (2006) argues that extra decisions must be made on different requirements for buying, negotiating, owning, and disposing of property; different culture, language, legal and political systems. Comparatively, foreign-owned are susceptible to competition from local owners and a considerable prominent risk operating as foreign SMEs. Per se, fear of the unknown and social issues such as xenophobia appear to contribute to the key challenges facing foreign SMEs in South Africa. Moreover, foreign SMEs face difficulties in accessing government loans. In most cases, they do not get such loans, and this reduces their capital and increases chances of business failure. Considering all these challenges the research focuses on how foreign-owned small businesses succeed despite the challenges on their disposal. It is against this background that the research attempted to examine those factors that determine the success of foreign-owned small 
businesses and make them compete effectively with local SMEs. The research was conducted in the towns of Alice, Fort Beaufort and King Williams Town in the Eastern Cape Province of South Africa.

\section{Research Objectives}

The main objective for this research was to identify the factors that contributed towards the success of foreign-owned businesses in the Eastern Cape Province of South Africa.

Secondary Objectives

- To identify the challenges faced by foreign-owned SMEs.

- To determine the effectiveness of entrepreneurial skills as a success factor.

- To determine the impact of marketing on the success of non-indigenous SMEs.

- To investigate whether or not managerial skills are necessary for the success of foreign small businesses.

- To ascertain the mediating role of home economy factors.

\section{Literature Review}

\subsection{Facts about SMEs in Africa}

In Africa, some key issues for policy development surrounding SMEs concern the determinants of the success of SMEs (Kauffmann, 2005). Evidence from a range of international studies points that while entrepreneurs are generally not in short supply in most African countries, only a small fraction of new enterprises will 'graduate' from birth to become small enterprises with more than 10 workers (Mead \& Liedholm, 1998). Despite their potential to contribute to the world economy, SMEs face many challenges. The Citigroup/EIU report cited inadequate access to financial resources and investment capital as significant barriers to growth for SMEs (Newberry, 2006). These challenges might have accounted for the high rates of failure among SMEs. Yip, Biscarri and Monti (2000) also go on to state that many SMEs suffer scale and resource disadvantages compared to their global rivals, adversely impacting the likelihood of success of their internationalisation initiatives.

An examination into the situation of African SMEs, globalisation meant that there would be no barriers to export, and access to technology and financial resources for the production of goods would be easier (Economic Commission for Africa, 2000). However, trading beyond borders has seen most African consumers buying more foreign goods and most African nations have had goods from other countries dominating their markets. Local markets have been invaded with second hand and cheaper products especially clothing from South East Asian countries like China, Malaysia and Taiwan. Hence, small scale enterprises have been more vulnerable than larger enterprises to the effects of liberalisation and globalisation. Globalisation has therefore had a direct negative impact on the growth of national African industries/enterprises and services (Economic Commission for Africa, 2000). The majority of African enterprises has failed to keep abreast with technological changes, and continues to face increasing competition from inflows of foreign goods. Coherently, the financial services of African countries has not adequately met the needs of local SME enterprises and as such African SMEs still operate within unstable, unregulated, unintegrated and uncompetitive environments. In the Democratic Republic of Congo, for example, most SMEs went bankrupt in the 1990s as a result of looting in 1993 and 1996 or during the civil war (Kauffmann, 2005). Africa's SMEs have little access to finance, which subsequently, hampers their emergence and eventual growth. Their main sources of capital are their retained earnings and informal savings and loan associations (tontines), which are unpredictable, not very secure and have little scope for risk sharing because of their regional or sectoral focus (Economic Commission for Africa, 2000).

\subsection{SMEs in South Africa}

Since 1994, the South African economy has been faced with challenges of reintegration into the global economy as a result of policies that were skewed. To achieve the objective of economic growth through competitiveness, employment generation and income redistribution, small businesses have been actively promoted since 1995 (Tshabalala \& Rankhumise, 2006). Given South Africa's legacy of big business domination, constrained competition and unequal distribution of income and wealth, the smaller business sector is seen as important in generating employment and more equitable income distribution. It is also important in activating competition, exploiting both local and international niche markets and enhancing productivity and technical change (DTI, 2005). 
The SME sector is of particular interest to the government because of the important contributions it makes to employment creation and poverty reduction. In the developed world, statistics indicate that for every 10 jobs created, 7 are generated by SMEs (KNC and Associates, 2002). In South Africa, SMEs contribute 37\% to employment, which is important in the light of the decrease in formal employment (KNC and Associates, 2002). This sector also contributes about $30 \%$ to the GDP of the economy. This is compared to the $1 \%$ of large organisations that contribute $65 \%$ to the GDP and 46\% to employment (KNC and Associates, 2002).

\subsection{Problems Faced by Foreign-Owned SMEs}

It is estimated that the failure rate of SMEs is between $70 \%$ and $80 \%$. Problems encountered by small businesses are numerous and can be described amongst others as being environmental, financial or managerial in nature (StatsSA, 2009). Primarily, management can exert no control over exogenous problems that manifest themselves in the economic, socio-demographic, political, technological and international spheres (Cant, Strydom \& Jooste, 1999). The most prominent problems influencing SME success in this environment include the state of the economy, compliance with legislation, resource scarcity, HIVIAIDS, crime and corruption and rapidly changing technology (Brink, Cant \& Ligthelm, 2003). In the previously disadvantaged townships, for example, entrepreneurs experience problems with low demand and not enough knowledge of competitors, which is also due to the fact that they hardly ever conduct any marketing research on their competitors and the needs of their customers (Brink, et al., 2003).

Deficiencies in the internal environment are also a major cause of SME failures generally, and revolve around management skills, financial knowledge, lack of expertise in functional areas such as marketing and human resource management (Ligthelm \& Cant, 2002). Some of the problems emanating from these factors include specific management issues such as a lack of business management training and skills as well as a limited family business culture in South Africa. The other reasons for failure include the inability to act as an entrepreneur, to control business growth and overemphasis on financial rewards. Management actions and behaviour which are in deficiency include inability to set strategic goals, plan forward, reluctance to seek advice, lack of management commitment and unwillingness to adapt to change (Ligthelm \& Cant, 2002).

Financial management is a crucial field within the endogenous environment of SMEs that presents numerous potential obstacles (Falkena, Abedian, Blottnitz, Coovadia, Davel, Madungandaba, Masilela, \& Rees, 2001). Management competence is often determined by the availability of management and financial information. Lack of financial sources is often reported as the major obstacle experienced by SMEs. Financial issues important for business success are capital requirements, bookkeeping, financial planning, financial control, management of working capital and income generation (Brink, et al., 2003). South Africa has limited financial resources therefore, funding is a problem. In most instances, the commercial banks are not willing to provide funding because most of the entrepreneurs do not have collateral securities (Tshabalala \& Rankhumise, 2006).

\subsection{Key Success Factors of SMEs}

Within any given market segment, there are key success factors (i.e. reliable delivery, low running costs). It is essential for a firm to establish what these are and how well it compares with the closest competitors (McDonald, 2003). A key success factor is something which enables firms to clinch the business. Every industry has a number of key success factors that measure and determine success or failure (Tracy, 2007). Despite many challenges that foreign-owned SMEs face, they still manage to survive and grow in the market and sometimes even outperform local SMEs. So what is it that makes these SMEs survive even without government funding?

\subsubsection{Entrepreneurial Success Factors}

There are several factors influencing entrepreneur success. However, many small business owners are not aware of the concept of entrepreneurship. Obtaining the facts about becoming an entrepreneur before starting a business can help to ensure preparedness for the challenges ahead. There is no stated formula for entrepreneurship, but below are some key entrepreneurial factors.

SMEs' capacity to compete with large enterprises and their survival in the long-run depends substantially on their ability to do sustainable improvements in their competitiveness (Long, 2006). Constant innovation is necessary to improve the marketing strategies and processes and to maximise the delivery of customer benefits and satisfaction 
(Reedy \& Schullo, 2004). Businesses in the $21^{\text {st }}$ century are operating in rapidly changing environments characterised by high technological advancements which therefore require SMEs to continuously improve their products and services to match the changing needs of the customers.

Successful entrepreneurs do not take chances, but sometimes take calculated risks. Unsuccessful entrepreneurs, on the other hand, do not take any risks, or take expensive, impulsive decisions that they do not think through (Nieman \& Nieuwenhuizen, 2009). Readiness to take risks involves a preparedness to make use of opportunities that are identified, even if there is a possibility of financial loss.

Most successful entrepreneurs realise the importance of business relationships and have good relations with clients. They see personal relations as an important source of the enterprise and regard long term reputation as more important than short term benefits. In marketing, SMEs in general do not have the resources to explore their own markets. Instead, they depend heavily on their trading partners for marketing of their products, either within the framework of local production networks and subcontracting relationships or orders from customers (Tambunan, 2006). Self-confidence forms a basis for a positive attitude and approach, just like perseverance. A positive attitude and approach is closely related to human relations, and there are important qualities that contribute to leadership and successful entrepreneurship (Nieman \& Nieuwenhuizen, 2009).

Most enterprises start off as small businesses and through perseverance they develop and expand. Commitment to business refers to the willingness of entrepreneurs to commit their personal resources to the business. It is an indication of the level of confidence that entrepreneurs have in their business. Commitment means that entrepreneurs make personal sacrifices or extraordinary efforts to deal with a task. Perseverance is an indicator of the ability to take repeated or different actions to solve a problem or overcome obstacles (Nieman \& Nieuwenhuizen, 2009). Entrepreneurs who have a positive attitude towards their organisations believe in themselves despite setbacks, and are prepared to persevere in their efforts to ensure success.

\subsubsection{Managerial Success Factors}

Small firms adopt a variety of strategies, depending on industry characteristics and their own strengths, in order to compete against larger firms and other SMEs. Firstly, up to $80 \%$ of successful enterprises have a strategic plan with a planning period of one to two years (Blake, 2008). The ability to plan is a characteristic of leaders, and is critical to growth of small and large firms. Leadership and management skills are critical success factors to entrepreneurial success. Presumably, most successful entrepreneurs are capable leaders. They cannot succeed without subordinates, and they can seldom procure assistance without reflecting an unusual degree of commitment and loyalty (Blake, 2008). Probably through strong personality or with great dreams, however, they must influence others to follow them.

In order to gain a competitive advantage in any business environment, it is important to know who the competitors are and their business operations. Knowledge of one's competitors is important for the successful establishment, continued existence and growth of a business. To ensure a competitive advantage, successful entrepreneurs ensure better and unique offerings (Nieman \& Nieuwenhuizen, 2009). Capitalising on the weaknesses of the competitor or covering the gaps left by a competitor are strategic actions that businesses can utilise but with a fair knowledge on competition.

According to Appiah-Adu (1997), the relationship between market orientation and performance in large enterprises also applies to small businesses. Market orientation thus has a positive influence on the performance of SMEs. Successful entrepreneurs are market oriented. They understand who their target market is, the market's requirements and needs of customers and how to meet them profitably. The products and services of a market-oriented entrepreneur are developed to meet the needs of the clients. The market-oriented entrepreneur also positions the business in such a way as to differentiate it from competitors in order to ensure profitability and a competitive advantage.

Success of any business depends on superior products and services. Contemporarily, successful firms put concerns of their customers or clients first. This means a continuous improvement of the quality of products and services while keeping costs in check (Hellriegel, et al., 2004). Product quality is important because customers these days are more concerned about the quality rather than the price. Equally, important client service is a key success factor because it is consistent with many other success factors. Good service involves everything that influences the client positively (Moolman, 1996). By meeting the clients' expectations, entrepreneurs ensure client satisfaction.

An insight into financial concepts, knowledge of financial management, its importance and application as well as a bookkeeping accounting system are important factors that can contribute to success (Blake, 2008). To achieve the objectives of the enterprise, sound financial principles must be applied. For foreign-owners, a successful entrepreneur is 
conscientious and realises the importance of effective financial planning and control. Sufficient relevant experience that has been gained before starting one's own business is one of the most important determinants of success. A significant number of successful entrepreneurs started their own business in the same industry in which they worked for a few years (Luk, 1996). Successful entrepreneurs usually have sufficient knowledge and skills regarding their enterprise to ensure reasonable success.

Some 50 to 60 per cent of enterprises fail within the first three years as a result of mismanagement or incompetence. Entrepreneurs need assistance with the implementation of advice (Nieman, et al., 2004). Thus, another important key success factor for SMEs is the utilization of experts inside and outside the enterprise on some of the functions within the business, and also attending seminars and training sessions. Foreign-owned SMEs need to make use of advisers, for example, lawyers, accountants, bankers and business consultants because they are new to the business environment of the foreign land.

\subsubsection{Marketing Success Factors}

Luk's (1996) study found that quite a number of entrepreneurs attributed their success mainly to their marketing management abilities. Production and general management factors were not indicated as being that important. Good personal sales techniques were identified as the second most important functional ability of successful entrepreneurs. An effective niche market strategy is also an important factor that contributes to the success of SMEs. Currently, in marketing Customer Relationship Management (CRM) is becoming more of a key strategy for firms big and small. Although there are many divergent conceptualisations of relationship marketing, there is a widespread agreement that it is an integral strategic direction for confronting the challenges posed by the dynamic and progressively global competitive marketplace (Ballantyne, Christopher, \& Payne, 2003).

Of essence, if immigrant SMEs are to be successful they need effective and outstanding marketing skills. This involves formulating an effective product positioning by creating a unique, consistent, and recognisable customer perception about a firm's offering and image (Lamb, Hair, McDaniel, Boshoff, \& Terblance, 2008). Key to success is setting up a business in areas where there is high demand and where the customers are. Marketing positioning has been traditionally one of the key competitive strategies for survival by small firms. Alam (2010) defines market orientation as an organisational culture that most effectively creates the necessary behaviors for the creation of superior value for consumers. Narver \& Slater (1990) further describe market orientation as consisting of three behavioural components; customer orientation, competitor orientation and inter-functional coordination.

Technology has transformed almost every business including the barber shop (Reedy \& Schullo 2004). Technological advances enable the marketer to identify specific prospects and deliver specific products and services for consumption by specific target markets. Technological developments confront the business world continuously and it is therefore very important that small business enterprises adapt to these changes.

\section{Methodology}

A sample size of 50 foreign SMEs was considered adequate due to the nature of the research and it was expected that the information gathered from the small group would enable accurate judgement about the larger group. A questionnaire was used to collect data and personal interviews were also conducted with the owners of non indigenous SMEs in the three towns. The questionnaire composed of closed and open-ended questions of which the majority were closed-ended questions. The questionnaire was designed in such a way that minimal time was spent to complete the questionnaire thereby avoiding too much inconveniencing of respondents during their business times. Convenience random sampling technique was used and the target population for this study included all the non indigenous SMEs in Alice, Fort Beaufort and King Williams Town. This means the sample elements were chosen based on the judgement of the researchers. Due to geographical dispersion of sample units, budgetary constraints and difficulty of accessing these types of SME's convenience random sampling was deemed appropriate.

\section{Data Analysis and Results}

A chi-square test of association was used with a $95 \%$ confidence level. There were two hypotheses: $\mathrm{H}_{0}$ (null hypotheses) and $\mathrm{H}_{1}$ (alternative hypotheses) for each objective. Cronbach alpha was used for reliability with a value of 0.80 signifying that the instrument was reliable. Section A of the questionnaire aimed at finding out the demographics of the respondents 
and the distribution of different nationalities across the province. Of interest was the identifying of the popular countries common within the three areas. The following results were obtained.

Figure 1: Nationalities

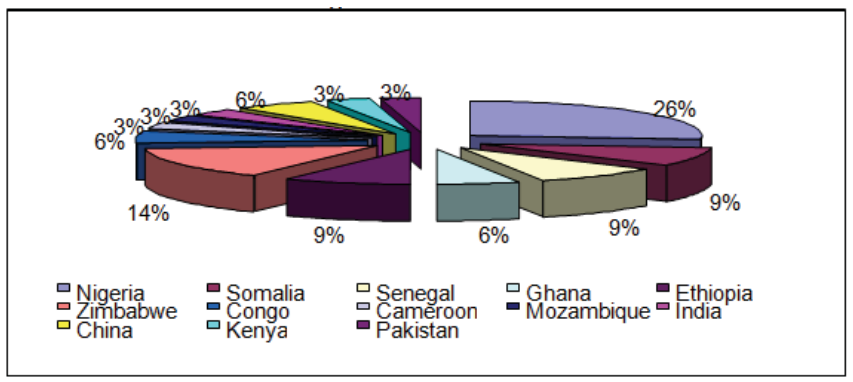

There were five research objectives and five research hypothesis for this research. These objectives and hypothesis were addressed by the interpretation of the research findings.

\subsection{Challenges Faced by Foreign-Owned SMEs}

From the results obtained there was a general agreement that all the listed challenges affected foreign-owned small businesses' success. Competition from other businesses had the highest average of $44 \%$ and a mean of 5.82 which, based on the 7-point likert scale; means that the respondents generally agree that competition from other businesses affects the success of their businesses. The use of unskilled labour, as a challenge, had the least effect on the success of foreign-owned small businesses. An average mean of 3.7 means that the majority of respondents neither disagreed nor agreed that using unskilled labour affects the success of their business. From the results, each challenge had a pvalue $<0.05$. Table 1 highlights analysis on each challenge as rated by the respondents on a 7-point likert scale.

From all the challenges that were identified the overall mean of all the challenges was 4.6 which means that all respondents generally agree to some extant that the selected challenges limit the success of their small businesses.

Table 1: Chi-square $\left(\mathrm{X}^{2}\right)$ results-Objective 1

\begin{tabular}{|l|c|c|c|}
\hline & Means & $X^{2}$-value & p-value \\
\hline Lack of funds & 4.65 & 14.72388 & $4.440892 \mathrm{E}-16^{*}$ \\
\hline Competition & 5.82 & 23.15973 & 0 \\
\hline Unskilled labour & 3.65 & 10.56254 & $4.040102 \mathrm{E}-12$ \\
\hline Technology & 4.41 & 14.33753 & $8.881784 \mathrm{E}-16$ \\
\hline Crime & 4.18 & 12.93666 & $1.776357 \mathrm{E}-14$ \\
\hline Unavailable resources & 4.65 & 15.58426 & 0 \\
\hline Low demand & 4.59 & 12.70914 & $2.908784 \mathrm{E}-14$ \\
\hline Discrimination & 4.44 & 12.73841 & $2.731149 \mathrm{E}-14$ \\
\hline Number of values & & 34 & \\
\hline
\end{tabular}

( ${ }^{\star} 4.440892 \mathrm{E}-16$ : the value has been raised to 16 decimal places, which applies for all the values like $4.040102 \mathrm{E}-12$ which also means the value has been raised to 12 decimal places).

The null hypothesis states that: foreign-owned SMEs do not face any challenges in the industry. From the results above, each challenge has a $p$-value $<0.05$. This therefore means $\mathrm{H}_{0}$ is rejected and a conclusion can be made that foreignowned SMEs face many challenges in the industry.

\subsection{Entrepreneurial Success Factors}

The second objective of the research sought to determine whether entrepreneurial skills are necessary for the success of foreign-owned small businesses. The results indicated a view that entrepreneurial skills are important for the success of 
foreign-owned small businesses. With a mean of 6.6 , commitment and motivation were perceived to be the most important of all the entrepreneurial success factors. The overall mean for all the factors of entrepreneurship was 5.9 meaning respondents generally view entrepreneurial success factors to be very important in order for them to succeed. With each entrepreneurial success factor having a p-value $<0.05$ it can be concluded that entrepreneurial skills are necessary for the success of small businesses. Table 2 gives statistics on how each entrepreneurial success factor was rated by the respondents on a 7-point likert scale.

Results indicated a view that entrepreneurial skills are important for the success of their foreign-owned businesses. With a mean of 6.6, commitment and motivation were perceived to be the most important of all the entrepreneurial success factors. The overall mean for all the factors of entrepreneurship was 5.9 meaning respondents generally view entrepreneurial success factors to be very important in order for them to succeed.

Table 2: Chi-square results-Objective 2

\begin{tabular}{|l|c|c|c|}
\hline & Means & $X^{2}$-value & $p$-value \\
\hline Creativity and innovation & 5.7 & 19.41009 & 0 \\
\hline Risk orientation & 5 & 20.74983 & 0 \\
\hline Good leadership & 4.9 & 16.05793 & $2.220446 \mathrm{E}-16$ \\
\hline Perseverance & 6.44 & 39.8596 & 0 \\
\hline Good human relations & 6.48 & 37.11231 & 0 \\
\hline Positive attitude & 6.37 & 34.69075 & 0 \\
\hline Commitment and motivation & 6.56 & 44.19276 & 0 \\
\hline Number of values & 5.92 & 34 & \\
\hline
\end{tabular}

The null hypothesis states that: entrepreneurial skills are not necessary for the success of small businesses. From the results shown, each entrepreneurial success factor has a $p$-value $<0.05$ meaning $\mathrm{H}_{0}$ is rejected and one can conclude that entrepreneurial skills are necessary for the success of small businesses.

\subsection{Marketing Success Factors}

The third objective of the research aimed to determine the impact of marketing on the success of foreign-owned SMEs. From the results obtained, each marketing success factor had a $p$-value $<0.05$ which therefore means that good marketing skills are a key success factor for foreign-owned SMEs. Customer relationship management is considered to be an important asset to have and from the results obtained it is clear that foreign small business owners also believe that having lasting business relations with their customers is key to success. With an average mean of 6.7 it is no doubt the most important marketing factor amongst foreign-owned SME owners and the respondents rated it as extremely important for business success. The responses on the importance of marketing success factors and how they were rated using a 7-point likert scale and using ratings, Table 3 was designed to allow the researchers to analyse objective 3 of the research.

Table 3: Chi-square results-Objective 3

\begin{tabular}{|l|c|c|c|}
\hline & Means & $X^{2}$-value & $p$-value \\
\hline Market orientation & 4.87 & 21.28848 & 0 \\
\hline Good positioning & 6.06 & 29.73177 & 0 \\
\hline Relationship management & 6.73 & 42.43028 & 0 \\
\hline Technology & 4.85 & 15.73665 & $2.220446 \mathrm{E}-16$ \\
\hline Number of values & 5.63 & 34 & \\
\hline
\end{tabular}

The null hypothesis states that: good marketing skills are not a key success factor for foreign-owned SMEs. From the results shown in Table 3, each marketing success factor has a p-value $<0.05$ which therefore means that $\mathrm{H}_{0}$ is rejected. Good marketing skills are a key success factor for foreign-owned SMEs. However, technology is not an essential factor for foreign owned SMEs. 


\subsection{Managerial Success Factors}

Of the managerial factors identified, the one that small business owners thought was of importance, and which had an average mean of 6.1, was good client service. At the bottom of the list is the use of experts with a mean of 4.1 which many small business owners, especially those in the clothing business, say is of no importance to the success of their business. With a mean of 5.5, the overall agreement on what the small business owners think or thought of managerial success factors is that they are moderately important for the success of their businesses. The null hypothesis states that: managerial skills do not contribute towards the success of foreign-owned small businesses. From the results in Table 4, most managerial success factor has a $\mathrm{p}$-value $<0.05$. $\mathrm{H}_{0}$ is therefore rejected and the conclusion is that managerial skills do contribute towards the success of foreign-owned small businesses.

Table 4: Chi-square results-Objective 4

\begin{tabular}{|l|c|c|c|}
\hline & Means & $X^{2}$-value & p-value \\
\hline Planning & 5.58 & 25.112 & 0 \\
\hline Knowledge of competitors & 5.73 & 19.77865 & 0 \\
\hline Mainly market oriented & 5 & 18.09473 & 0 \\
\hline Client service & 6.1 & 28.44975 & 0 \\
\hline High-quality work & 6.09 & 25.39933 & 0 \\
\hline Financial insight and management & 5.34 & 19.53369 & 0 \\
\hline Knowledge and skills of the business & 5.88 & 20.19164 & 0 \\
\hline The use of experts & 4.96 & 11.40425 & $8.286705 \mathrm{E}-13$ \\
\hline Number of values & & 34 & \\
\hline
\end{tabular}

\subsection{The Mediating role of Home Economy Factors}

Asked whether they had been in business in their home countries before moving to South Africa, $82 \%$ of the respondents responded in the affirmative whereas the other $18 \%$ said they had not been in business before. The decision to move to another country is a difficult one but most foreign SME owners say that the need for a better life pushes them to make that decision. Poor economies, war, unavailability of markets, famine and poverty in the different home countries are some of the reasons behind the increase in the number of foreign-owned small businesses in South Africa.

Table 5: Chi-square results-Objective 5

\begin{tabular}{|c|c|c|}
\hline & $X^{2}$-value & $p$-value \\
\hline Yes & 48.1235 & 0 \\
\hline No & 10.53662 & $4.031012 \mathrm{E}-12$ \\
\hline Number of Values & 34 & \\
\hline
\end{tabular}

The null hypothesis states that: home country factors do not motivate foreigners to start small businesses in South Africa. From the results above, $p<0.05$. This therefore means $\mathrm{H}_{0}$ is rejected so home country factors motivate foreigners to start small businesses in South Africa.

\section{Conclusions and Recommendations}

Based on the analysed data, it is clear that most foreign-owned SMEs by Africans in the province are in the clothing business whereas the groceries business has a smaller representation. Many foreign nationals have started small businesses in the clothing industry catering for the small towns. However, because competition is high from large retail outlets like Shoprite and Spar, the groceries business is the least popular with foreign small business owners.

As established in the study, foreign-owned SMEs are performing exceptionally well in the business environment despite of numerous challenges that they face. While challenges differ from one small business to the other, the most common challenge that these foreign-owned SMEs of African descent face is lack of funding from either the local government or the banking sector. This is largely due to the fact that most owners of foreign small businesses enter the country illegally and do not have the necessary documents to apply for bank loans. But, even with the necessary 
documents, local banks do not offer loans to foreigners because most foreigners do not have collateral security. Without the funding from Government and banks, it is up to the foreign nationals to find ways of succeeding in a highly competitive business environment where both large and small businesses exert a lot of pressure. Hard work is what is required and a lot of dedication and commitment to the business. For most foreigners, there is pressure from the fact that they cannot return to their home countries due to different circumstances that made them leave.

The results from the collected data show that entrepreneurial factors are valued the most followed by marketing and then managerial factors. As for managerial factors, even though important for small business owners, are not that prevalent amongst foreign-owned SMEs as compared with large firms where the number of employees is high and a lot of paper work is needed. Whilst success factors differ from one business to another, there are some that all businesses identify as being extremely important for the business to succeed. For example, there was a general consensus from the respondents that creativity and innovativeness are a prerequisite for any small business owner. One has to be creative and innovative so that one's products can be different from the competitors'. Local customers are also encouraged to buy from foreigners because they offer a lot of variety from what is already in the local market. For example, many foreignowned hair salons have different ways of braiding hair that is different from their local counterparts.

For some nationalities, e.g. Somalis, much of their success is based on the spirit of togetherness. They have formed an association named Somali Association of South Africa (SASA) which has offices in King Williams Town. Through this association they help each other with different business ideas. Other nationalities can also form their own associations or all the foreign nationals can form an association for foreign small business owners.

\section{References}

Alam, M.M. (2010). Effect of Market Orientation on Small Business Performance in Small Town in Malaysia: An empirical study on Malaysian Small Firms. Manage. Mark. J., 8(1): 91-104.

Appiah-adu, K. (1997). Market orientation and performance: do the findings established in large firms hold in the small business sector? J. Euro Marketing, 6(3): 1-26.

Ballantyne, D., Christopher, M. \& Payne, A. (2003). 'Relationship marketing: Looking back, looking forward. Marketing Theory, 3(1): 15966.

Blake, B. S. (2008). The Principal as Entrepreneur in the Management of Schools. Masters in Education, University of Johannesburg, South Africa: Johannesburg.

Botha, M. \& Esterhuyzen, E. (2013). The perceived capabilities and willingness of South African small business owners to act as business mentors. African Journal of Business Management Vol. 7(5), pp. 331-343.

Brink, A., Cant, M. \& Ligthelm, A. (2003). Problems Experienced By Small Businesses in South Africa. [On-line] Available: http://www.cecc.com.au/programs (Accessed: 25 October, 2010).

Cant, M.C., Strydom, J.W. \& Jooste, C.J. (1999). Essentials of marketing. Kenwyn: Juta, South Africa.

DTI (Department of Trade and Industry) - South Africa. (2005). White Paper on National Strategy for the Development and Promotion of Small Business in South Africa. WPA/ 2005).Economic Commission for Africa, 2000:13

ECONOMIC COMMISSION FOR AFRICA. (2000). Transforming Africa's Economies. [On-line] Available: http://www.uneca.org (Accessed 19 October 2010).

Falkena, H., Abedian, I., Blottnitz, M., Coovadia, C., Davel, G., Madungandaba, J., Masilela, E. \& Rees, S. (2001). "SMEs' Access to Finance in South Africa, A Supply-

Side Regulatory Review", The Task Group of the policy Board for Financial Services and Regulation. [On-line] Available: www.finance.gov.za/documents/smes (Accessed 28 October 2010).

Hellriegel, D., Jackson, S.E., Slocum, J., Staude, G., Amos, T., Klopper, H.B., Louw, L. \& Oosthuizen, T. (2004). Management. Oxford University Press Southern Africa, South Africa: Cape Town.

Kauffmann, C. (2005). Financing Small and Medium Enterprises in Africa. African Development Bank and OECD Development Centre, African Economic Outlook (2004-2005).

KNC \& Associates. (2002). Access to finance. Presentation to APDF Conference.

Kotler, P. \& Keller, K. L. (2006). Marketing Management. Pearson Education Inc. Upper Saddle River, USA: New Jersey.Ligthelm \& Cant, 2002:3).

Lamb, C.W., Hair, J.F., Mcdaniel, C., BOshoff, C. \& Terblance, N.S. (2006). Marketing. Oxford University Press Southern Africa, South Africa: Cape Town.

Ligthelm, A.A. \& Cant, M.C. (2002). Business success factors of SMEs in Gauteng. Pretoria: University of South Africa.

Long, N.V. (2006). 'Performance and obstacles of SMEs in Viet Nam Policy implications in near future', paper, International IT Policy Program (ITPP) Seoul National University, Seoul. [On-line] Available: http://www.docstoc.com/docs/44786454/Development-ofSmall-and-Medium-Enterprises-in-a-Developing (Accessed 19 September 2010).

Luk, T.K. (1996). Success in Hong Kong: factors self-reported by successful small business owners. Journal of Small Business Management, 34(3): 68-74. 
Mcdonald, M. (2003). Marketing plans: how to prepare them, how to use them. Butterworth-Heinemann. UK: Oxford.Mead \& Liedholm, 1998:65.

Mead, D.C. \& Liedholm, C. (1998). The dynamics of micro and small enterprises in

developing countries. World Development, 26: 61-74.

Moolman, P.L. (1996). The win characteristics of the successful entrepreneur. Entrepreneur, 96(6): 4-6.

Narver, J.C. \& Slater, S.F. (1990). "The Effect of a Market Orientation on Business Profitability." J. Marketing, 54 (October): 20-35.

Newberry, D. (2006). The Importance of Small and Mid Sized Enterprise in Emerging Economies. [On-line] Available: http://www.wri.org/climate/topic_content.cfm?ci (Accessed 7 October, 2010).

Nieman, G., Hough, J. \& Nieuwenhuizen, C. (2004). Entrepreneurship: A South African Perspective. Van Schaik Publishers, South Africa: Pretoria.

Nieman, G. \& Nieuwenhuizen, C. (2009). Entrepreneurship: A South African Perspective. Van Schaik Publishers. South Africa: Pretoria.

Pangarkar, N. (2008). "Internationalization and Performance of Small and Medium Sized Enterprises". Journal of World Business, 43(4): $475-485$.

Reedy, J. \& Schullo, S. (2004). Electronic Marketing. Integrating Electronic Resources into the Marketing Process. Thompson SouthWestern, USA.

Reuber, B \& Fischer, E. (1998). Small successes. CA Magazine, 131(1): 36-37.

StatsSA (2009). Investor's Handbook. [On-line] Available: http://www.thedti.gov.za/publications/lnvestor (Accessed 28 Sept 2010).

Tambunan, T.T.H. (2006). Development of Small \& Medium Enterprises in Indonesia from the Asia-Pacific Perspective, LPFE-Usakti, Jakarta. [On-line] Available: http://www.gim2008.ca/conference_proceedings/Tambunan (Accessed 28 September 2010).

Tracy, B. (2007). The 100 Absolutely Unbreakable Laws of Business Success. Berrett-Koehler Publishers, USA: California.

Tshabalala, D.B. \& Rankhumise, E.M. (2006). Competence and Critical Success Factor Development as an Avenue for Achieving Sustainable Micro and Small Enterprises in Africa.

van Vuuren, J.J. (2002). Entrepreneurship training for emerging SMEs in South Africa. (Global Perspective). J.of Small Business Manage: $1-9$.

Yip, G.S., Biscarri, J.G. \& Monti, J.A. (2000). The role of the internationalisation process in the performance of newly Internationalising firms, J. Int. Mark, 8(3):10-35. 